\title{
МЕЖДУНАРОДНО-ПРАВОВЫЕ АСПЕКТЫ И ВОПРОСЫ ОТВЕТСТВЕННОСТИ ПРИ ПРИВЛЕЧЕНИИ ЧАСТНЫХ ВОЕННЫХ И ОХРАННЫХ ПРЕДПРИЯТИЙ К ОСУЩЕСТВЛЕНИЮ МИРОТВОРЧЕСКИХ ОПЕРАЦИЙ ООН
}

\begin{abstract}
Аннотация: Деятельность частных военных и охранных предприятий сегодня представляет собой один из наиболее динамично развивающихся сегментов бизнес-сферы, связанной собеспечением безопасности. Однако наибольшееколичество правовых вопросов возникает, когда частные военные и охранные предприятия задействуются в области, которая не ассоциируется с частным сектором - области поддержания международного мира и безопасности. Привлечение данных предприятий к реализации миротворческой функиии ООН порождает массу вопросов правового характера, которые нуждаются в рассмотрении и осмыслении. При работе над статьей использовались документы Организации Объединенных Наций, сравнивались позици чиновников ООН по вопросу привлечения частных структур косуществлению важнейшей миротворческой функиии организации, а также были проанализированы различные, порой весьма противоречивые, мнения представителеймеждународно-правовой доктрины. Очевидно, что из-за участившихся в последниегоды случаев привлечения частных военных и охранных предприятий кучастию в миротворческой деятельности Организации Объединенных Наиий, анализ юридических аспектов данного участия приобретает все больщую актуальность. Кроме того, в академическом мире наблюдается явная диспропориия - западные исследователи уже активно публикуются по данной проблеме, а в отечественной науке публикачии на данную тему практически отсутствуют.

Abstract: The activities of private military and security companies is now one of the most dynamically growing segments of the business sphere on security guarantees. However, the largest quantity of legal issues appears, when private military and security enterprises are involved in the sphere, which is not associated with the private sector, such as peacekeeping and protection of global security. Involvement of such companies to implementation of the peacekeeping function of the UNO causes a large number of legal questions, which need to be addressed and analyzed. In the process of writing the article the author used the documents of the United Nations Organizations, compared the positions of the UN officials on the issue of involvement of private structures to implementation of the foremost important peacekeeping function of the organization. The author also analyzed various and at times contradictory opinions of the representatives of the international legal doctrine. It is obvious that since in late years there was a growing number of situation of involvement of private military and security companies in the peacemaking activities of the UN, the analysis of the legal aspects of such participation becomes more and more topical. Additionally, there is an obvious disproportion in the academic world, since the Western legal scholars actively publish their opinions on this issue, while there is almost no publications on this issue among the Russian scholars. Ключевые слова: Международная ответственность, международное право, миротворческие операции, применение силь, миротворчество, Организация Объединенных Наций, частные военные предприятия, правовые аспекты, наемничество, конфликты.
\end{abstract}

Keywords: International responsibility, international law, peacekeeping operations, use of force, peacekeeping, the United Nations Organization, private military companies, legal aspects, mercenaries, conflicts.

первые частные военные и охранные предприятия были привлечены к работе на Организацию Объединенных Наций около двадцати лет назад, и первоначально их функции сводились лишь к тыловому обеспечению миссии, непосредственное их участие в миротворческих операциях не предполагалось. В 1997 г. бывший Генеральный секретарь ООН К. Аннан в ответ на вопрос, будет ли ООН использовать ЧВОП в своей миротворческой деятельности (речь шла о привле- чении контрактников во время очередного кризиса в Руанде), сказал ставшую знаменитой фразу, что «человечество не готово приватизировать мир». ${ }^{1}$ Тем не менее, события последних двадцати лет свидетельствуют как раз таки о неуклонной «привати-

\footnotetext{
${ }^{1}$ Speech given by the UN Secretary General at Ditchley Park UK, 26 June 1998, UN Press Release SG/SM/6613; and Transcript of Press Conference by Secretary General Kofi Annan at UN Headquarters on June 12, 1997, SG/SM/6255.
} 


\section{Право и политика 4 (172) $\bullet 2014$}

зации применения силы»². Необходимо отметить, что западные исследователи активно публикуются по данной проблеме ${ }^{3}$. Безусловно, ввиду важности миротворческой проблематики представителям отечественной доктрины международного права надлежит восполнить этот пробел.

Весьма показательной стала гражданская война в Сьерра-Леоне в 1992 г., когда из-за слабой технической оснащенности и низкого уровня подготовки миротворческая миссия ООН была свернута, и правительство Сьерра-Леоне обратилось к частной южноафриканской военной компании Executive Outcomes, которая помогла быстро стабилизировать ситуацию в стране и даже спасла от гибели нескольких ооновских миротворцев. После первых успехов, 1996 - 2005 гг. ЧВОП участвовали в работе международных полицейских миссий ООН в Боснии и Герцеговине, Косово и Метохии. При этом большую роль в данных операциях сыграла корпорация из США DynCorp, «осуществлявшая набор личного состава для американского контингента международных полицейских сил, а также участвовавшая в проверках работы персонала этих миссий» ${ }^{4}$. В 2003 г. и в 2009 г. компания DynCorp также выиграла контракт с Государственным департаментом США для участия в миротворческих операциях на африканском континенте.

Компания Defence Systems Limited (DSL) начала с контракта с миссией UNPROFOR в Боснии в 1992 г., а также предоставляла своих сотрудников для миссий ЮНИСЕФ в Судане и Сомали. ${ }^{5}$ Контракт с DSL длился четыре года, до тех пор, пока контроль над операцией не перешел к НАТО в 1996 г. Один из бывших руководителей DSL Д. Рамсботтам, утверждал, что привлечение компании к данной операции позволило «компенси-

\footnotetext{
${ }^{2}$ Волеводз А.Г. Международно-правовое регулирование деятельности частных военных и охранных предприятий (ЧВОП): современный этап международного правотворчества// Библиотека криминалиста. М.: Юрлитинформ, 2012. № 1 (2). с. 235.

${ }^{3}$ Spearin C. UN Peacekeeping and the International Private Military and Security Industry//International Peacekeeping. Vol. 18. No. 2. 2011; Bures $O$. Private Military Companies: A Second Best Peacekeeping Option?//International Peacekeeping. Vol. 12. No. 4. 2005; Patterson M. A Corporate Alternative to United Nations Ad Hoc Military Deployments//Journal of Conflict \& Security Law. Vol. 13. No. 2. 2008; O'Brien K. Military Advisory Groups and African Security: Privatized Peacekeeping// International Peacekeeping. Vol. 5. 1998.

${ }^{4}$ Мукин Ю. Использование гражданских контрактников и частных вооружённых формирований в современных конфликтах// Зарубежное военное обозрении, №7, 2008. с.28.

${ }^{5}$ Vaux T., Seiple C., Nakano G. Humanitarian Action and Private Security Companies. Opening the Debate. London, International Alert, 2001.
}

ровать нехватку военного и гражданского персонала $\mathrm{OOH} »^{6}$. При этом необходимо отметить, что сотрудники DSL «носили гражданскую форму сотрудников $\mathrm{OOH}$, имели при себе ооновские бейджи и документы, и были полностью включены в состав UNPROFOR».?

На сайте компании Pacific Architects \& Engineers (PAE) указано, что она предоставляла персонал для сотрудников гражданской полиции в миссиях ООН на Гаити и в Либерии. ${ }^{8}$ Кроме того, данная компания предоставляла услуги миссии ООН в Сьерра-Леоне в 2000 и 2003 гг, а также миссии ООН в Конго в $2001^{9}$. Именно в период операции в Конго в полной мере проявилась специфика задействования ЧВОП в миротворческих операциях. В июне 2004 г. произошло нападение конголезцев на миссию ООН в ответ на то, что миротворцы не смогли предотвратить кровопролитие в провинции Итури. Сотрудники компании Pacific Architects $\&$ Engineers внешне были неотличимы от миротворцев ООН, носили ооновскую форму, и, естественно, также подверглись нападению. Триста сотрудников миссии ООН потребовали у местных властей их эвакуации из города, и в результате часть сотрудников РАЕ обеспечивала эвакуацию, а часть осталась в Конго выполнять свои обязательства по контракту.

ЧВОП Paramount Group активно сотрудничает с развивающимся странами в области тренировки будущих миротворцев. Компании Aegis и Global Risk неоднократно нанимались для охраны сотрудников Секретариата ООН в Ираке ${ }^{10}$. Предприятие International Charters Inc. успешно участвовало в миротворческих операциях ООН в Судане, Конго, Руанде и Либерии, осуществляя охрану миссий, складов и предоставляя свои вертолеты и технику. Кроме того, ЧВОП могут предоставлять не только военный персонал, но юристов и технических специалистов. Уже неоднократно упоминавшееся предприятие DynCorp отправило в миссию OOH в Судане UNMIS пятнадцать специалистов юридического профиля.

\footnotetext{
${ }^{6}$ Select Committee on Foreign Affairs, Private Military Companies. Ninth Report of Session 2001-2002. London: The Stationery Office, 2002. p. 76.

${ }^{7}$ Ostensen A. UN Use of Private Military and Security Companies Practices and Policies. The Geneva Centre for the Democratic Control of Armed Force, 2011. p.16.

${ }^{8}$ См. официальный сайт компании Pacific Architects \& Engineers (PAE) URL:https://www.pae.com/career-justice-support-description

${ }^{9}$ Chatterjee P. Darfur Diplomacy: Enter the Contractors// Corpwatch, 2004. URL: www.corpwatch.org/article.php?id $=11598$.

${ }^{10}$ Cockayne J. Commercial Security in Humanitarian and Post-Conflict Settings - An Explorative Study. New York, International Peace Academy, 2006. p.6.
} 
Среди основных партнеров ООН официально заявлены такие предприятия, как ArmorGroup, DynCorp, Global Risks, PAE, Aegis Defence Services, Gray Security Services, Hart Security UK, MPRI Inc., Steele North America, Armor Group Training ${ }^{11}$.

Таким образом, можно констатировать, что частные военные и охранные предприятия сегодня фактически «являются равноправным правовым субъектом наряду с регулярной армией и другими силовыми структурами» ${ }^{12}$. В этой связи неизбежно встает вопрос o «законности их деятельности с точки зрения международного права» ${ }^{13}$. У данной проблемы существует два основных аспекта: во-первых, правовой статус данных предприятий, а также вопрос их ответственности в случае превышения своих полномочий или же злоупотребления силой.

В наши дни обозначилась тенденция, в рамках которой «основной контингент миротворцев ООН составляют солдаты из Пакистана, Нигерии, Уругвая, Кении, Ганы, Бангладеш и Индии. Многие из тех, кто служил в войсках $\mathrm{OOH}$ еще 10 лет назад, - французы, британцы, американцы, итальянцы и канадцы-перешли в частные компании». ${ }^{14}$

В личном составе самих ЧВОП, в свою очередь, наблюдаются две противоположные тенденции. С одной стороны, изначально туда шли более подготовленные по сравнению с обычными призывниками военные: «Рассмотрим стандартное прошлое сотрудников ЧВОП - бывшие члены спецназа или же других элитных подразделений британской, американской или другой национальной армии, которые, возможно, были привлечены финансовыми стимулами, предлагаемыми частным сектором» ${ }^{15}$. С другой стороны, из-за стремительного развития частного военного бизнеса потребность в кадрах стоит достаточно остро, из-за чего ЧВОП принимают на работу граждан из стран третьего мира, многие из которых обладают сомнительной биографией.

\footnotetext{
${ }^{11}$ List of Vendors on Provisional Status by Country of Origin//UN Office of Central Support Services, Procurement Division, 2011. URL: www.un.org/depts/ptd/pdf/vendors.pdf.

${ }^{12}$ Коновалов И.П., Валецикий О.В. Эволюция частных военных компаний. Пушкино: Центр стратегической конъюнктуры, 2013. с. 9.

${ }^{13}$ Волеводз А.Г. Международно-правовое регулирование деятельности частных военных и охранных предприятий (ЧВОП): современный этап международного правотворчества// Библиотека криминалиста. М.: Юрлитинформ, 2012, № 1 (2). с. 233.

${ }^{14}$ Кизиитов К., Симонова М., Дашковский И., Частные армии на \$200 млрд// РБК, 1 мая 2011 г. URL: http://magazine.rbc. $\mathrm{ru} / 2011 / 05 / 01 / \mathrm{main} / 562949980354228 . \mathrm{shtml}$

${ }^{15}$ Brayton S. Outsourcing War: Mercenaries and the Privatization of Peacekeeping//Journal of International Affairs. No. 55. 2002. p.311.
}

В 1998 г. в Секретариате ООН был разработан документ, называющийся «Десять правил: кодекс поведения «голубых касок» ${ }^{16}$. К числу приоритетных задач миротворца, согласно данному документу, относятся уважение правовой системы той страны, куда они прибыли с миссией, приоритет прав человека, а также нераспространение любой информации, которая может негативно сказаться на репутации ООН. На фоне стремления к экономической выгоде, которое традиционно является основным императивом для частных компаний, о соблюдении этических положений, сформулированных в Кодексе, речь не идет: «Сотрудники частных военных предприятий, привлекаемые к участию в миротворческих операциях, обычно воспринимаются негативно, как люди, ведомые лишь финансовыми соображениями, а не патриотизмом. Голубые каски, напротив, имеют более высокие интересы и представляют авторитет народов мира в целом» $»^{17}$.

С другой стороны, аргумент относительно того, что сотрудники ЧВОП работают не за идею, а за деньги, также легко может быть оспорен, так как миротворцы также получают жалование, хоть и существенно меньшее, чем сотрудники частных военных и охранных предприятий, а, кроме того, репутация самих миротворцев ООН далеко не безупречна: «Например, в Косово и Восточном Тиморе, миротворцы были причастны к изнасилованиям, убийствам и даже геноциду». ${ }^{18}$

Также очевидно, что сотрудников частных предприятий и миротворцев ООН неизбежно сравнивают с позиции технической оснащенности и уровня военной подготовки, причем в данном случае сравнение зачастую не в пользу ООН, что сказывается на имидже организации в целом. А в области поддержания безопасности, на частном, государственном или международном уровне, именно имидж зачастую играет важнейшую роль: «Это сфера, где репутация - это все».19

С юридической точки зрения, одним из главных вопросов в данном случае является вопрос о том, являются ли сотрудники частных военных и охранных

\footnotetext{
${ }^{16}$ Ten Rules: Code of Personal Conduct For Blue Helmets http://cdu. unlb.org/UNStandardsofConduct/TenRulesCodeofPersonalConductForBlueHelmets.aspx

${ }^{17}$ Richemond D. The New Peacekeepers? Private Military Companies and the Future of Peacekeeping Operations//European Society of International Law Working Paper Agora Series. 2007. URL: www.idc. ac.il/publications/files/461.

${ }^{18}$ Rawski F. To Waive or Not To Waive: Immunity and Accountability in U.N. Peacekeeping Operations//Connecticut Journal of International Law. No. 18. 2002. p. 118.

${ }^{19}$ Brooks D. Messiahs or Mercenaries? The Future of International Private Military Services// International Peacekeeping, No. 7. 2000. p. 141.
} 


\section{Право и политика 4 (172) $\bullet 2014$}

предприятий наемниками или же нет. От ответа на данный вопрос зависит то, насколько вообще возможно их привлечение к осуществлению миротворческих операций ООН: «Привлечение ЧВОП к выполнению операций, связанных с использованием силы от имени ООН, НАТО или любой региональной организации поднимает вопрос о том, насколько вообще контрактники правомочны применять силу в рамках действующего международного права». ${ }^{20}$

Первый возможный ответ на данный вопрос «сотрудники ЧВОП не являются наемниками». В рамках данной парадигмы обосновывается идея того, что наемники и сотрудники частных военных структур, в силу ряда признаков, принадлежат к различным проявлениям одного явления, однако, с правовой точки зрения, их нельзя считать взаимозаменяемыми понятиями. Они представляют собой разные исторические стадии одного и того же явления, и, с точки зрения родовых понятий, сотрудников частных военных и охранных предприятий вполне можно назвать «наемниками XXI века» и продолжателями «диких гусей» и «солдатов удачи» прошлого, однако их правовой статус при этом совсем другой, так как международное право существенно изменилось. В рамках данной точки зрения ООН вполне может позволить себе привлекать ЧВОП к своей деятельности.

Второй вариант возможного ответа - «сотрудники ЧВОП все же являются наемниками». Соответственно, использование их в операциях ООН в рамках данной парадигмы попросту противоправно, так как организация, которая выступает против наемничества, но при этом сама использует труд наемников - это явно не пример логичного и последовательного поведения, особенно для всемирного гаранта стабильности.

Поскольку разные должностные лица в различных докладах и интервью высказывают различные, порой прямо противоположные, точки зрения, бывает весьма затруднительно понять, а в чем же заключается «официальная позиция» $\mathrm{OOH}$ по тем или иным вопросам. Еще десять-пятнадцать лет назад, согласно позиции некоторых ооновских чиновников, сотрудники ЧВОП являлись наемниками и их привлечение являлось незаконным. ${ }^{21}$ Однако к сегодняшнему дню

\footnotetext{
${ }^{20}$ Richemond $D$. The New Peacekeepers? Private Military Companies and the Future of Peacekeeping Operations//European Society of International Law Working Paper Agora Series. 2007. URL: www.idc. ac.il/publications/files/461.

${ }^{21}$ См., например, Ballesteros E.B. Report on the question of the use of mercenaries as a means of violating human rights and impeding
}

ситуация сильно изменилась. В 2011 г. Департамент безопасности ООН по безопасности начал разработку рекомендаций для более ответственной и прозрачной работы частных предприятий на службе ООН. Именно поэтому вполне возможно, что «изначально негативное отношение ООН к деятельности ЧВОП, и без того поколебленное неоднократными обращениями ООН к их услугам - может быть преодолено, если компании продолжат работать над улучшением своего имиджа» ${ }^{22}$.

Компромиссом между полярными позициями «привлекать - не привлекать» частные военные компании является позиция, заключающаяся в том, что привлекать контрактников необходимо, однако лишь в качестве сопровождающих лиц, осуществляющих «логистику операции или охрану миротворцев» ${ }^{23}$, без их непосредственного участия в военных действиях. Помимо весьма печальной констатации, что, оказывается, миротворцев тоже нужно защищать, данная позиция имеет массу «слабых звеньев» и потенциально создает весьма обширную почву для злоупотреблений. Очевидно, что в ситуации гражданской войны - а это наиболее типичные условия работы современных миротворцев - крайне сложно разделить функции лиц сопровождающих и лиц, активно участвующих в событиях. Разделить после подобных операций, кто и над чем осуществлял контроль, попросту невозможно.

Тем не менее, одним из важнейших аргументов «за» большее вовлечение частных военных и охранных предприятий в миротворческую деятельность ООН является специфика проведения миротворческих операций. С учетом того, что на учреждение полноценной миротворческой миссии под эгидой Организации Объединенных Наций требуется от недели до нескольких месяцев, привлечение ЧВОП в ситуации, когда ООН еще официально не вмешалась в урегулирование конфликта, может стать существенным фактором, причем как стабилизации, так и дестабилизации ситуации - в зависимости от реакции населения, профессионализма сотрудников ЧВОП, целей и задач предстоящей операции.

Поскольку развертывание миротворческой операции представляет собой весьма небыстрый процесс, может показаться, что привлечение ЧВОП позволяет

the exercise of the right of peoples to self-determination. Commission Resolution 1998/6, E/CN.4/1999/11, 13 January 1999.

${ }^{22}$ Richemond $D$. The New Peacekeepers? Private Military Companies and the Future of Peacekeeping Operations//European Society of International Law Working Paper Agora Series. 2007. URL: www.idc. ac.il/publications/files/461.

${ }^{23}$ Singer P. W. Should Humanitarians Use Private Military Services?// Humanitarian Affairs Review. 2004. p.14. 
начать операцию максимально быстро, фактически сразу же после получения мандата Совета Безопасности ООН. Именно поэтому не приходится удивляться, что уже всерьез обсуждаются перспективы полного перехода миротворческой функции к ЧВОП, «особенно в ситуациях, когда государства не могут или не хотят открыто вмешиваться в конфликт». ${ }^{24}$ В качестве возможных плюсов подобного перехода называют «специализированность, опыт и гибкость». ${ }^{25}$ Логика в данном случае весьма проста-зачем тратить деньги и время на подготовку и обучение миротворцев, если уже готовые профессионалы военного дела готовы приступить к работе немедленно? Именно поэтому все чаще можно услышать о том, что «приватизация миротворчества становится предпочтительным вариантом для развитых стран, нежелающих вмешиваться в растущий хаос региональных конфликтов. ${ }^{26}$

Однако возникает следующий вопрос, который необходимо решить - «по какому критерию необходимо отбирать военную компанию из множества претендентов» для участия в миротворческой операции? ${ }^{27}$ Устраивать тендер и тем самым окончательно коммерциализировать сферу миротворчества? «Хотя данный вариант - устраивать тендер для каждой миротворческой операции - может показаться наиболее справедливым, он может вызвать больше проблем, чем классическое использование возможностей $\mathrm{OOH}$ и НАТО. Одно из главных преимуществ привлечения частных предприятий - это то, что они могут начать действовать значительно раньше, чем ООН или НАТО - соответственно долгий процесс найма может существенно увеличить процесс» ${ }^{28}$. Таким образом, складывается ситуация замкнутого круга, когда ключевые преимущества контрактников связаны именно с их «полулегальным» статусом.

\footnotetext{
${ }^{24} O$ 'Brien K. Military Advisory Groups and African Security: Privatized Peacekeeping//International Peacekeeping, Vol.5. 1998. p. 98.

${ }^{25}$ Brooks D. Messiahs or Mercenaries? The Future of International Private Military Services// International Peacekeeping, No. 7. 2000. p. 138.

${ }^{26}$ O'Brien K. Military Advisory Groups and African Security: Privatized Peacekeeping//International Peacekeeping, Vol.5. 1998. p. 102.

${ }^{27}$ Kristen F. Casualties in Evolving Warfare: Impact of Private Military Firms' Proliferation on the International Community// Wisconsin International Law Journal. Vol. 23. 2005. p. 775.

${ }^{28}$ Richemond $D$. The New Peacekeepers? Private Military Companies and the Future of Peacek Richemond D. The New Peacekeepers? Private Military Companies and the Future of Peacekeeping Operations// European Society of International Law Working Paper Agora Series. 2007. URL: www.idc.ac.i1/publications/files/461.eeping Operations// European Society of International Law Working Paper Agora Series. 2007. URL: www.idc.ac.il/publications/files/461.
}

Также совершенно очевидно, что в условиях весьма значительного количества конфликтов, ООН просто физически не может обеспечить функционирование необходимого количества миротворческих миссий по всему миру. Потребность в миротворцах неуклонно возрастает. В 2007 г. США начали программу Global Peace Operations Initiative, предполагающую обучение 75 тысяч миротворцев, в основном из Африки. Стоимость программы составила 81 млн. долларов. Аналогичный проект был начат и в рамках самого африканского континента - African Crisis Response Initiative (ACRI), и предполагает обучение 12 тысяч человек, которые при необходимости могли бы встать в ряды миротворцев ООН либо же миротворческой операции, проводимой на региональном уровне.

Кроме того, также как и государства, ООН стремится минимизировать статистику по потерям и затратам на военные операции, и в данном контексте именно привлечение частных предприятий может сыграть свою роль, так как потери их личного состава не учитываются в официальных сводках.

Существуют два способа привлечения сотрудников частных военных предприятий к участию в миротворческих операциях $\mathrm{OOH}$ - во-первых, непосредственное привлечение через Департамент миротворческих операций, а во-вторых, вариант, когда сами странычлены организации направляют сотрудников ЧВОП в качестве части выделяемого для миротворческой операции контингента. Более десяти лет назад в своем исследовании Дж.Талби утверждал, что «для участия в миротворческих операциях США направляет зачастую не членов регулярной армии, а сотрудников частных военных компаний» ${ }^{29}$.

Определение ответственности за правонарушения, совершенные частными военными и охранными предприятиями, привлеченными к осуществлению миротворческих операций ООН, многократно усложняет и без того непростую проблему международной ответственности. Возьмем для иллюстрации данной ситуации вышеупомянутую миссию $\mathrm{OOH}$ в СьерраЛеоне. Операция проводлась под эгидой ООН, однако $\mathrm{OOH}$ привлекла к операции предприятие Executive Outcomes, которое, в свою очередь, зарегистрировано в США и фактически подконтрольно американскому правительству. Или другой пример из этой же серии: «До апреля 2004 г. DynCorp International был единственным поставщиком кадров для миссии UNCIVPOL, поэтому

\footnotetext{
${ }^{29}$ Taulbee J.L. The Privatization of Security: Modern Conflict, Globalization and Weak States//Civil Wars. Vol. 5. No. 2. 2002. p. 5.
} 


\section{Право и политика 4 (172) • 2014}

каждый американец из этой миссии был сотрудником DynCorp $»^{30}$. Как в данном случае решать проблему ответственности? Очевидно, что существующих международно-правовых механизмов явно недостаточно.

Многое в международных отношениях также зависит от ракурса, и Д.Брукс, председатель объединения нескольких крупнейших частных военных предприятий International Stability Operations Association и выразитель идеологии частного военного бизнеса, считает противоправным не использование частных компаний, a, наоборот, неиспользование такой замечательной возможности. В своей статье с говорящим названием «Выпишите чек, остановите войну» он утверждает, что важен результат, а не юридические тонкости: «Трагедия состоит в том, что мы не используем этот ресурс, который готов принести мир, стабильность и политическую свободу на африканский континент». ${ }^{31}$

Тем не менее, «подозрительность по отношению к ЧВОП сохраняется на достаточно высоком уровне, что во многом объясняет нежелание расширять их участие в миротворческих операциях». ${ }^{32}$ Вопрос о том, что же такое ЧВОП для миротворчества - проклятие или благословение, по-прежнему остается предметом ожесточенных споров.

\section{Библиография:}

1. Волеводз А.Г. Международно-правовое регулирование деятельности частных военных и охранных предприятий (ЧВОП): современный этап международного правотворчества// Библиотека криминалиста. М., Юрлитинформ, 2012. № 1 (2).

2. Кизиитов К., Симонова М., Дашковский И., Частные армии на \$200 млрд// РБК, 1 мая 2011 г. http://magazine. rbc.ru/2011/05/01/main/562949980354228.shtml

3. Коновалов И.П., Валецкий О.В.Эволюция частных военных компаний. Пушкино: Центр стратегической конъюнктуры, 2013.

4. Мукин Ю. Использование гражданских контрактников и частных вооружённых формирований в

\footnotetext{
${ }^{30}$ Serafino N. Policing in Peacekeeping and Related Stability Operations: Problems and Proposed Solutions. Washington, the Library of Congress, Congressional Research Service, 2004. p. 9.

${ }^{31}$ Brooks D. Write a Check, End a War. Using Private Military Companies to End African Conflicts//Conflict Trends. 2000. p. 35.

${ }^{32}$ Richemond $D$. The New Peacekeepers? Private Military Companies and the Future of Peacekeeping Operations//European Society of International Law Working Paper Agora Series. 2007. URL: www.idc. ac.il/publications/files/461.
}

современных конфликтах//Зарубежное военное обозрении, №7, 2008.

5. Официальный сайт компании Pacific Architects \& Engineers (PAE) URL:https://www.pae.com/careerjustice-support-description

6. Ballesteros E.B. Report on the question of the use of mercenaries as a means of violating human rights and impeding the exercise of the right of peoples to self-determination. Commission Resolution 1998/6, E/CN.4/1999/11, 13 January 1999.

7. Brayton S. Outsourcing War: Mercenaries and the Privatization of Peacekeeping//Journal of International Affairs No. 55, 2002.

8. Brooks D. Messiahs or Mercenaries? The Future of International Private Military Services// International Peacekeeping, No. 7, 2000.

9. Brooks D. Write a Check, End a War. Using Private Military Companies to End African Conflicts//Conflict Trends. 2000.

10. Bures O. Private Military Companies: A Second Best Peacekeeping Option?//International Peacekeeping. Vol. 12. No. 4. 2005.

11. Chatterjee P. Darfur Diplomacy: Enter the Contractors// Corpwatch, 2004. URL: www.corpwatch.org/article. php?id=11598.

12. Cockayne J. Commercial Security in Humanitarian and Post-Conflict Settings - An Explorative Study. New York, International Peace Academy, 2006.

13. Kristen F. Casualties in Evolving Warfare: Impact of Private Military Firms' Proliferation on the International Community// Wisconsin International Law Journal. Vol. 23. 2005.

14. List of Vendors on Provisional Status by Country of Origin//UN Office of Central Support Services, Procurement Division, 2011. URL: www.un.org/depts/ ptd/pdf/vendors.pdf.

15. O'Brien K. Military Advisory Groups and African Security: Privatized Peacekeeping//International Peacekeeping, Vol.5. 1998.

16. Ostensen A. UN Use of Private Military and Security Companies Practices and Policies. The Geneva Centre for the Democratic Control of Armed Force, 2011. P.16.

17. Patterson M. A Corporate Alternative to United Nations Ad Hoc Military Deployments//Journal of Conflict \& Security Law. Vol. 13. No. 2. 2008.

18. Rawski F. To Waive or Not To Waive: Immunity and Accountability in U.N. Peacekeeping Operations// Connecticut Journal of International Law. No. 18, 2002.

19. Richemond D. The New Peacekeepers? Private Military Companies and the Future of Peacekeeping 
Operations//European Society of International Law Working Paper Agora Series. 2007. URL: www.idc. ac.il/publications/files/461

20. Select Committee on Foreign Affairs, Private Military Companies. Ninth Report of Session 2001-2002. London: The Stationery Office, 2002.

21. Serafino N. Policing in Peacekeeping and Related Stability Operations: Problems and Proposed Solutions. Washington, the Library of Congress, Congressional Research Service, 2004.

22. Singer P. W. Should Humanitarians Use Private Military Services?//Humanitarian Affairs Review. 2004.

23. Spearin C. UN Peacekeeping and the International Private Military and Security Industry//International Peacekeeping. Vol. 18. No. 2. 2011.

24. Speech given by the UN Secretary General at Ditchley Park UK, 26 June 1998, UN Press Release SG/SM/6613; and Transcript of Press Conference by Secretary General Kofi Annan at UN Headquarters on June 12, 1997, SG/SM/6255.

25. Taulbee J.L. The Privatization of Security: Modern Conflict, Globalization and Weak States//Civil Wars. Vol. 5. No. 2. 2002.

26. Ten Rules: Code of Personal Conduct For Blue Helmets http://cdu.unlb.org/UNStandardsofConduct/ TenRulesCodeofPersonalConductForBlueHelmets. aspx

27. Vaux T., Seiple C., Nakano G. Humanitarian Action and Private Security Companies. Opening the Debate. London, International Alert, 2001.

28. Разумов Ю.А. Некоторые конституционно-правовоые особенности реализации норм международного права в военной сфере в зарубежных странах // NB: Международное право. - 2013. - № 1. - C.171-183. DOI: 10.7256/2306-9899.2013.1.684. URL: http:/e-notabene.ru/wl/article_684.html

29. Каламкарян Р.А. Роль Международного Суда ОOH в деле поддержания международного правопорядка // NB: Международное право. - 2013.-№ 1.C.184-214. DOI: 10.7256/2306-9899.2013.1.690. URL: http://e-notabene.ru/wl/article_690.html

30. Кривенкова М.В. Формы нематериальной ответственности международных организаций // NB: Международное право. - 2012. - № 1. - C.1-15. DOI: 10.7256/2306-9899.2012.1.367. URL: http://e-notabene. ru/wl/article_367.html

31. Сазонова К.Л. Международно-правовая ответственность международных организаций: проблемы и перспективы // NB: Международное право. - 2012.-№ 1.-C.16-25. DOI: 10.7256/2306-
9899.2012.1.371. URL: http://e-notabene.ru/wl/ article_371.html

32. Сазонова К.Л. «Большая пятерка» и миротворческая деятельность Организации Объединенных Наций: политические и правовые вызовы и угрозы // NB: Международное право. - 2013.-№ 2.-C.1-15. DOI: 10.7256/2306-9899.2013.2.4769. URL: http://enotabene.ru/wl/article_4769.html

33. Каламкарян Р.А. Включенность Российской Федерации в деятельность Международного Суда ООН в деле обеспечения международной законности и правопорядка // NB: Международное право. - 2013. - № 2. - C.85-118. DOI: 10.7256/23069899.2013.2.691. URL: http://e-notabene.ru/wl/ article_691.html

34. Саврыга К.П.. Частные военные и охранные компании по международному праву // Международное право и международные организации / International Law and International Organizations. - 2013. - № 4. - C. 456-464. DOI: 10.7256/2226-6305.2013.4.10098.

35. Костенко Н.И.. Роль Организации Объединенных Наций по решению проблем правосудия переходного периода и господства права в конфликтных // Международное право и международные организации / International Law and International Organizations. - 2013. - № 4. - C. 560-571. DOI: 10.7256/2226-6305.2013.4.10012.

36. Бабин Б.В.. Право на мир: в поисках механизма реализации // Международное право и международные организации / International Law and International Organizations. - 2013. - № 2. - C. 156167. DOI: 10.7256/2226-6305.2013.2.8808.

37. Карпович О.Г.. Международно-правовые основы миротворческой деятельности США // Международное право и международные организации / International Law and International Organizations. - 2013. - № 2. - C. 251-264. DOI: 10.7256/2226-6305.2013.2.8085.

38. М.В. Кешнер. Комитеты по санкциям Совета Безопасности ООН как институциональный механизм реализации международных санкций // Международное право и международные организации / International Law and International Organizations. - 2013. - № 1. - C. 23-28. DOI: 10.7256/2226-6305.2013.01.2.

39. М.В. Кривенкова. Некоторые вопросы нематериальной ответственности международных организаций // Международное право и международные организации / International Law and International Organizations. - 2012. - № 4. - C. 122-126. 


\section{Право и политика 4 (172) 2014}

40. Д. Э. Видус. Вопрос о группах охраняемых, конвенцией «О предупреждении преступления геноцида и наказании за него» и идентификации жертв геноцида // Международное право и международные организации / International Law and International Organizations. - 2012. - № 3. - C. 16-27.

41. К. Л. Сазонова. Основные аспекты международноправовой ответственности международных организаций // Международное право и международные организации / International Law and International Organizations. - 2012. - № 3. - C. 124-128.

42. А. Р. Хагуш. Роль международных двусторонних договоров в регулировании военно-технического сотрудничества России с иностранными государствами // Международное право и международные организации / International Law and International Organizations. - 2012. - № 2. - C. 124-132.

43. Г. Г. Шинкарецкая. Международное правои мирное урегулирование // Международное право и международные организации / International Law and International Organizations. -2011. - № 3. - C. 144-150

44. Сазонова К.Л. Институт ответственности государств за применение силы: современное состояние и перспективы развития // NB: Вопросы права и политики. - 2012. - 3. - C. 78 - 91. URL: http:/ www.e-notabene.ru/lr/article_255.html

\section{References (transliteration):}

1. Volevodz A.G. Mezhdunarodno-pravovoe regulirovanie deyatel'nosti chastnykh voennykh i okhrannykh predpriyatii (ChVOP): sovremennyi etap mezhdunarodnogo pravotvorchestva// Biblioteka kriminalista. M., Yurlitinform, 2012. № 1 (2).

2. Kiziitov K., Simonova M., Dashkovskii I., Chastnye armii na \$200 mlrd// RBK, 1 maya $2011 \mathrm{~g}$. http://magazine.rbc.ru/2011/05/01/main/562949980354228.shtml

3. Konovalov I.P., Valetskii O.V.Evolyutsiya chastnykh voennykh kompanii. Pushkino: Tsentr strategicheskoi kon"yunktury, 2013.

4. Mukin Yu. Ispol'zovanie grazhdanskikh kontraktnikov i chastnykh vooruzhennykh formirovanii v sovremennykh konfliktakh//Zarubezhnoe voennoe obozrenii, №7, 2008.

5. Ballesteros E.B. Report on the question of the use of mercenaries as a means of violating human rights and impeding the exercise of the right of peoples to self-determination. Commission Resolution 1998/6, E/CN.4/1999/11, 13 January 1999.
6. Brayton S. Outsourcing War: Mercenaries and the Privatization of Peacekeeping//Journal of International Affairs No. 55, 2002.

7. Brooks D. Messiahs or Mercenaries? The Future of International Private Military Services// International Peacekeeping, No. 7, 2000.

8. Brooks D. Write a Check, End a War. Using Private Military Companies to End African Conflicts//Conflict Trends. 2000.

9. Bures O. Private Military Companies: A Second Best Peacekeeping Option?//International Peacekeeping. Vol. 12. No. 4. 2005.

10. Chatterjee P. Darfur Diplomacy: Enter the Contractors// Corpwatch, 2004. URL: www.corpwatch.org/article. php?id=11598.

11. Cockayne J. Commercial Security in Humanitarian and Post-Conflict Settings - An Explorative Study. New York, International Peace Academy, 2006.

12. Kristen F. Casualties in Evolving Warfare: Impact of Private Military Firms' Proliferation on the International Community// Wisconsin International Law Journal. Vol. 23. 2005.

13. O'Brien K. Military Advisory Groups and African Security: Privatized Peacekeeping//International Peacekeeping, Vol.5. 1998.

14. Ostensen A. UN Use of Private Military and Security Companies Practices and Policies. The Geneva Centre for the Democratic Control of Armed Force, 2011. P.16.

15. Patterson M. A Corporate Alternative to United Nations Ad Hoc Military Deployments//Journal of Conflict \& Security Law. Vol. 13. No. 2. 2008.

16. Rawski F. To Waive or Not To Waive: Immunity and Accountability in U.N. Peacekeeping Operations// Connecticut Journal of International Law. No. 18, 2002.

17. Richemond D. The New Peacekeepers? Private Military Companies and the Future of Peacekeeping Operations// European Society of International Law Working Paper Agora Series. 2007. URL: www.idc.ac.il/publications/files/461

18. Select Committee on Foreign Affairs, Private Military Companies. Ninth Report of Session 2001-2002. London: The Stationery Office, 2002.

19. Serafino N. Policing in Peacekeeping and Related Stability Operations: Problems and Proposed Solutions. Washington, the Library of Congress, Congressional Research Service, 2004.

20. Singer P. W. Should Humanitarians Use Private Military Services?//Humanitarian Affairs Review. 2004.

21. Spearin C. UN Peacekeeping and the International Private Military and Security Industry//International Peacekeeping. Vol. 18. No. 2. 2011. 
22. Taulbee J.L. The Privatization of Security: Modern Conflict, Globalization and Weak States//Civil Wars. Vol. 5. No. 2. 2002.

23. Vaux T., Seiple C., Nakano G. Humanitarian Action and Private Security Companies. Opening the Debate. London, International Alert, 2001.

24. Razumov Yu.A. Nekotorye konstitutsionno-pravovoye osobennosti realizatsii norm mezhdunarodnogo prava v voennoi sfere $\mathrm{v}$ zarubezhnykh stranakh // NB: Mezhdunarodnoe pravo. - 2013.-№ 1.-S.171-183. DOI: 10.7256/2306-9899.2013.1.684. URL: http://e-notabene. $\mathrm{ru} / \mathrm{wl} /$ article_684.html

25. Kalamkaryan R.A. Rol' Mezhdunarodnogo Suda OON $\mathrm{v}$ dele podderzhaniya mezhdunarodnogo pravoporyadka // NB: Mezhdunarodnoe pravo. - 2013.-№ 1.S.184-214. DOI: 10.7256/2306-9899.2013.1.690. URL: http://e-notabene.ru/wl/article_690.html

26. Krivenkova M.V. Formy nematerial'noi otvetstvennosti mezhdunarodnykh organizatsii // NB: Mezhdunarodnoe pravo. - 2012.-№ 1.-S.1-15. DOI: 10.7256/2306-9899.2012.1.367. URL: http://e-notabene. $\mathrm{ru} / \mathrm{wl} /$ article_367.html

27. Sazonova K.L. Mezhdunarodno-pravovaya otvetstvennost' mezhdunarodnykh organizatsii: problemy i perspektivy // NB: Mezhdunarodnoe pravo. - 2012.-№ 1.-S.16-25. DOI: 10.7256/2306-9899.2012.1.371. URL: http://e-notabene.ru/wl/article_371.html

28. Sazonova K.L. «Bol'shaya pyaterka» i mirotvorcheskaya deyatel'nost' Organizatsii Ob"'edinennykh Natsii: politicheskie i pravovye vyzovy i ugrozy // NB: Mezhdunarodnoe pravo. - 2013.-№ 2.-S.1-15. DOI: 10.7256/2306-9899.2013.2.4769. URL: http://enotabene.ru/wl/article_4769.html

29. Kalamkaryan R.A. Vklyuchennost' Rossiiskoi Federatsii v deyatel'nost' Mezhdunarodnogo Suda OON v dele obespecheniya mezhdunarodnoi zakonnosti i pravoporyadka // NB: Mezhdunarodnoe pravo. - 2013.-№ 2.-S.85-118. DOI: 10.7256/23069899.2013.2.691. URL: http://e-notabene.ru/wl/article_691.html

30. Savryga K.P.. Chastnye voennye i okhrannye kompanii po mezhdunarodnomu pravu // Mezhdunarodnoe pravo i mezhdunarodnye organizatsii / International Law and International Organizations. - 2013. - № 4. - S. 456464. DOI: 10.7256/2226-6305.2013.4.10098.

31. Kostenko N.I.. Rol' Organizatsii Ob"edinennykh Natsii po resheniyu problem pravosudiya perekhodnogo perioda i gospodstva prava v konfliktnykh // Mezhdunarodnoe pravo i mezhdunarodnye organizatsii / International Law and International Organizations.
- 2013. - № 4. - S. 560-571. DOI: 10.7256/22266305.2013.4.10012.

32. Babin B.V.. Pravo na mir: v poiskakh mekhanizma realizatsii // Mezhdunarodnoe pravo i mezhdunarodnye organizatsii / International Law and International Organizations. - 2013. - № 2. - S. 156-167. DOI: 10.7256/2226-6305.2013.2.8808.

33. Karpovich O.G.. Mezhdunarodno-pravovye osnovy mirotvorcheskoi deyatel'nosti SShA// Mezhdunarodnoe pravo i mezhdunarodnye organizatsii / International Law and International Organizations. - 2013. - № 2. S. 251-264. DOI: 10.7256/2226-6305.2013.2.8085.

34. M.V. Keshner. Komitety po sanktsiyam Soveta Bezopasnosti OON kak institutsional'nyi mekhanizm realizatsii mezhdunarodnykh sanktsii // Mezhdunarodnoe pravo i mezhdunarodnye organizatsii / International Law and International Organizations. - 2013. - № 1. - S. 23-28. DOI: 10.7256/22266305.2013.01.2.

35. M.V. Krivenkova. Nekotorye voprosy nematerial'noi otvetstvennosti mezhdunarodnykh organizatsii // Mezhdunarodnoe pravo i mezhdunarodnye organizatsii / International Law and International Organizations. 2012. - № 4. - S. 122-126.

36. D. E. Vidus. Vopros o gruppakh okhranyaemykh, konventsiei «O preduprezhdenii prestupleniya genotsida $\mathrm{i}$ nakazanii za nego» i identifikatsii zhertv genotsida // Mezhdunarodnoe pravo i mezhdunarodnye organizatsii / International Law and International Organizations. 2012. - № 3. - S. 16-27.

37. K. L. Sazonova. Osnovnye aspekty mezhdunarodnopravovoi otvetstvennosti mezhdunarodnykh organizatsii // Mezhdunarodnoe pravo i mezhdunarodnye organizatsii / International Law and International Organizations. - 2012. - № 3. - S. 124-128.

38. A. R. Khagush. Rol' mezhdunarodnykh dvustoronnikh dogovorov v regulirovanii voenno-tekhnicheskogo sotrudnichestva Rossii s inostrannymi gosudarstvami // Mezhdunarodnoe pravo i mezhdunarodnye organizatsii / International Law and International Organizations. 2012. - № 2. - S. 124-132.

39. G. G. Shinkaretskaya. Mezhdunarodnoe pravoi mirnoe uregulirovanie // Mezhdunarodnoe pravo i mezhdunarodnye organizatsii / International Law and International Organizations. - 2011. - № 3. - S. 144-150

40. Sazonova K.L. Institut otvetstvennosti gosudarstv za primenenie sily: sovremennoe sostoyanie i perspektivy razvitiya // NB: Voprosy prava i politiki. - 2012. 3. - C. 78 - 91. URL: http://www.e-notabene.ru/lr/ article_255.html 